\title{
International Economic Law in the Global South and COVID-19
}

\author{
James T. Gathii, Olabisi D. Akinkugbe, Titilayo Adebola, Nthope Mapefane and \\ Ohio Omiunu
}

\section{$\underline{\text { Introduction }}$}

The COVID-19 pandemic has disrupted all facets of human relations on a magnitude not witnessed in the post-World War II era. Due to the interdependence of countries in the international system, it is not surprising that the unfolding public health crisis has had significant ramifications for the functioning of the global economy as well. In responding to this global health crisis, and the associated fallouts, many of which will only become apparent many months from now, the academic community has a crucial role to play in finding solutions to the hydra-headed problems we all face. Most notably in the International Economic Law (IEL) space, the gravity of the task is evident, as the world braces itself for the extended socio-economic fallouts of the pandemic. More so in Africa and the broader global south, which has pre-existing fragilities, unique peculiarities and inherent complexities, researching the impact of the crisis from an IEL perspective is imperative.

Driven by this sense of urgency and responsibility, AfronomicsLaw put out a call for contributions in April 2020 for a symposium issue focusing on COVID-19 and International Economic Law in the Global South. The response to the call for contributions was overwhelming. 37 essays made the final list for the symposium issue. The essays in this Symposium came from Africa, Asia, Europe, the Middle East, the Caribbean, North America and Latin America. This Symposium will last for a full four weeks because of the large number of good quality submissions we accepted. While many of the essays address cross-cutting themes, the essays have been grouped into four major themes.

In the first week, the Symposium will be comprised of a series of thoughtful and insightful contributions centering around International Trade and International Investment Law and Policy. In the second week, the Symposium will focus on Intellectual Property, Technology and Agriculture. The essays cover crucial intellectual property law conundrums such as the conflict between incentivizing innovation through private rights, on the one hand, and promoting the public interest through affordable access, on the other. In addition, the symposium contributions will address issues relating to technology such as those relating to remote working, teaching and learning. Another highlight in week 2 relates to questions about food and agriculture raised by the pandemic. In week three, the Symposium will focus on the important issues the COVID-19 pandemic raises relating to Sovereign Debt, Finance and Competition Law. The essays in week three will focus on the consequences for each of these issue areas, including the slowdown of the global economy occasioned by the COVID-19 pandemic. The contributions also critically assess various proposals to address the impacts of the pandemic on sovereign debt and public finance. Finally, in Week 4, the Symposium will focus on Governance, Rights and Institutions. The excellent contributions will examine how institutions at the national, sub-regional, regional and 
international levels have grappled to address the often-difficult governance issues that arise in a time of a massive global pandemic and the variety of ways in which our rights have been affected.

\section{WEEK ONE}

The first day of the Symposium will feature a Keynote Interview that our Contributing Editor, Dr. Amaka Vanni, conducted with the President of African Export-Import Bank, (Afreximbank), Professor Ben Oramah on the bank's responses to the COVID-19 pandemic. ${ }^{1}$ Afronomicslaw.org is very grateful to Professor Oramah for his interview.

Of particular interest to our readers is his discussion of the Afreximbank's Pandemic Trade Impact Mitigation Facility (PATIMFA) designed to assist Afreximbank member countries in managing the adverse impact of health, financial and economic shocks caused by epidemics, such as the COVID-19 pandemic Professor Oramah also discusses the types of support Afreximbank has been extending to support the African Continental Free Trade Agreement (AfCFTA). In addition, if you have not heard of the Pan-African Payment and Settlement System (PAPSS), which is a new regulatory framework for cross-border payments and settlements in Africa, this interview will tell you all about it.

After this keynote interview, the Symposium will publish a series of essays. Daniel Omoro Achach and Patrick Wasonga Anam, for example, will reflect on the global rush for personal protective equipment in the context of regional value chains. ${ }^{2}$ Next, Chibole Wakoli, of the WTO Appellate Body Secretariat, discusses some important cross-cutting issues the COVID-19 pandemic raises. ${ }^{3}$ Concluding that the pandemic justifies prioritizing Africa's regional integration project, she argues Africa's vulnerabilities have been laid bare. Thus without freer trade flows to ensure access to food, without better infrastructure to support such flows, without addressing the debt burden or the fragile health care systems, African economies would not be ready to take care of the most vulnerable among us. This theme of vulnerability runs throughout the Symposium. For example, in David A. Gantz and Basha H. Malkawi's essay helpfully contextualizes the impact of prior pandemics on the global economy, including large reductions in imports and exports. ${ }^{4}$ Like other contributors, they argue that until testing is widely available, and there is an effective vaccine, the adverse impacts on the global economy will continue.

Nojeem Amodu's essay reflects on how free trade zones can be mobilized during the pandemic to produce personal protective equipment and exports to respond to health care

\footnotetext{
${ }^{1}$ Interview by Dr. Amaka Vanni with Prof. Ben Omramah, “On COVID-19, AfCFTA and the Role of the Afreximbank as Pan-African Multilateral Trade Finance Institution," AfronomicsLaw (May 4, 2020).

${ }^{2}$ Daniel Omoro Achach \& Patrick Wasonga Anam, "Of the Global Rush for Personal Protective Equipment, Regional Value Chains and Lessons for Africa," AfronomicsLaw (May 5, 2020).

${ }^{3}$ Chibole Wakoli, "COVID-19 in Africa: A time for Despair or an Opportunity to Change the Direction of Travel?” AfronomicsLaw (May 5, 2020).

${ }^{4}$ David A. Gantz \& Bashar H. Malkawai, "Short and Fast or Long and Slow? The Economic Impact of the Coronavirus," AfronomicsLaw (May 6, 2020).
} 
needs and to help economies stay afloat. ${ }^{5}$ In her essay, Sendra Chihaka argues that to enhance value addition and the production of complementary products, Africa needs to engage in regional value chains under which each country specializes in the manufacture of components that they can produce competitively. ${ }^{6}$ For example, Tanzania can specialize in the production of sugar and Kenya in refining it for further processing into chocolates. Southern Africa countries, she argues, can take advantage of South Africa as the industrial hub for manufacturing and processing of minerals.

Marie-Valerie Uppiah discusses why the pandemic is an opportunity for African countries to improve port infrastructure and invest in freight technology. ${ }^{7}$ This is not only because commercial shipping is playing an important role in ensuring the availability of essential medical supplies, food and other commodities while air transport is largely halted, but also because of its economic and strategic significance for African landlocked and coastal states.

Francis Kofi Korankye-Sakyi and Timothy Masiko in their separate contributions make a case for positioning the AfCFTA and Africa's regional integration agenda at the forefront in recovery efforts. For his part, Masiko argues that like the lockdown/contact-tracing decision, integration decisions must be made quickly and on a large scale and most importantly, consistently followed through to their completion. ${ }^{8}$ Francis Kofi KorankyeSakyi emphasizes paying particular attention to the role played by Micro, Small and Medium Enterprises (MSMEs) which he argues constitute a significant percentage of the trading activities in Africa. ${ }^{9}$

Franziska Sucker ponders the implications the COVID-19 pandemic has unleashed in Africa in terms of digital trade. She examines the challenges of teleworking and in particular of bridging the digital divide and facilitating physical-distant work/opportunities, especially in poorer African countries. ${ }^{10}$ She closes by reflecting on how the AfCFTA might help close these gaps. Tinyiko Ngobeni, for his part, reflects on the types of regulatory measures States may take in the context of international investment law to legitimately address the consequences of the COVID-19 pandemic. ${ }^{11}$ For example, he discusses some of the domestic judicial challenges that have already been brought against governments by alcohol retailers, hot food retailers and tobacco manufacturers. He argues there is a likelihood of similar cases brought by investors under international investment

\footnotetext{
${ }^{5}$ Nojeem Amodu, "Free Zones, COVID-19 Lockdown, and 'the Morning After,", AfronomicsLaw (May 6, 2020).

${ }^{6}$ Sendra Chihaka, "COVID-19: Africa's Chance to take Advantage of Regional Production,"

AfronomicsLaw (May 7, 2020).

${ }^{7}$ Marie Valeria Uppiah, "The COVID-19 Pandemic: An Opportunity for African States to Review their Shipping Industry Strategy,” AfronomicsLaw (May 7, 2020).

${ }^{8}$ Timothy Masiko, "Globalisation and COVID-19: What can African International Economic Law Learn?" AfronomicsLaw (May 8, 2020).

${ }^{9}$ Francis Kofi Korankye-Sakyi, "Fighting the COVID-19 Today: A Reflection on Positioning the AfCFTA for the Future," AfronomicsLaw (May 8, 2020).

${ }^{10}$ Franziska Sucker, "COVID-19 pushes digital solutions and deepens digital divides: What role for African digital trade law?" AfronomicsLaw (May 9, 2020).

${ }^{11}$ Tinyiko Ngobeni, "State Responsibility for COVID-19 Regulatory Measures under International

Economic Law," AfronomicsLaw (May 9, 2020).
} 
treaties. He concludes that only when the COVID-19 dust has settled will it be known which states had robust, well-crafted COVID-19 regulatory measures that can survive investor claims.

Nanjira Annabel returns to the trade theme in her discussion of national restrictions placed on exports of personal protective equipment under WTO law. ${ }^{12}$ She discusses the restrictions under the obligations of Articles XI of GATT and then under the exceptions in Articles XX and XXI thereof. Her analysis then creatively extends to the permissibility of these measures under the AfCFTA. Her analysis discusses the many interpretive difficulties surrounding the permissibility of quantitative restrictions to address the COVID-19 pandemic. She also notes that these difficulties have arisen in other recent cases that have invoked security-based justifications for departing from the fundamental building blocks of the global trading regime that prohibit such restrictions.

J. Jason Cotton, Jan Yves Remy and Alicia Nicholls return to the theme of vulnerability, this time focusing on the Caribbean and their innovative proposal of a Trade Vulnerability Index at the WTO. ${ }^{13}$ The index uses proxies for export concentration, limited diversification and dependence on strategic imports to build their index. They argue that COVID-19 has renewed its relevance with an urgency. Similarly, Clair Gammage and Olabisi D. Akinkugbe return to this theme on vulnerability and argue that there are three emerging narratives in South-South Trade and Investment Cooperation. ${ }^{14}$ In addition, their essay brings China's complex role into the discussion. China has provided support for many countries with supplies of medical supplies. Yet Gammage and Akinkugbe note the discrimination against blacks in China. They argue this discrimination reflects and accentuates the racialized dimension of the trade, investment and labour relations between African countries and China.

Ocholla Akoth's essay argues that Least Developed Countries LDCs are inadequately equipped to manage the socio-economic impact that comes with the Covid-19 pandemic. $^{15}$ She notes that the sustainable development goals strategies did not envisage such a pandemic, and this is causing many governments to lose sight of how to manage their economic downturns they are experiencing. She concludes that national governments and the international community, therefore, have to be more vigilant and proactive in ensuring that these particularly vulnerable countries are able to stabilize their economies after the pandemic.

Week 1 of the Symposium closes with Matiangai Sirleaf's essay on COVID-19 and Africa that wonderfully wraps up some of the major themes of the week. ${ }^{16}$ Her essay shows how

\footnotetext{
${ }^{12}$ Nanjira Annabel, "Justifying COVID-19 Exportation-Related Quantitative Restrictions within the framework of the World Trade Organization Law," AfronomicsLaw (May 10, 2020).

${ }^{13}$ J. Jason Cotton, Jan Yves Remy \& Alicia Nicholls, "COVID-19 Makes the Case for Our Trade Vulnerability Index," AfronomicsLaw (May 10, 2020).

${ }^{14}$ Clair Gammage \& Olabisi D. Akinkugbe, "Covid-19 and South-South Trade \& Investment Cooperation: Three Emerging Narratives," AfronomicsLaw (May 11, 2020).

${ }^{15}$ Ocholla Akoth, "International Economic Law in the Shadow of COVID-19: Perspectives from Least Developed Countries," AfronomicsLaw (May 12, 2020).

${ }^{16}$ Matiangai Sirleaf, “Africa, COVID-19 and Responsibility,” AfronomicsLaw (May 12, 2020).
} 
health issues are inextricably connected to international trade and international investment law. She reminds us that although the African continent has systemic healthcare vulnerabilities, these countries can draw on the resilience, creativity and innovations learnt from prior epidemics. Most significantly, she shows how the historical role of international financial institutions have limited domestic health spending and capacity in a way that has made addressing the pandemic more difficult for African countries. Her essay ends with a proposal she refers to as a common but differentiated framework for responsibility to recognize special situations of need when an epidemic arises so as to then assign responsibilities depending on which countries have more resources or capacities.

\section{WEEK TWO}

As noted above, in the second week, the Symposium will focus on Intellectual Property, Technology and Agriculture. Caroline Ncube's essay focuses on the preparedness of South Africa's higher education sector for teaching in the age of COVID $19 .{ }^{17}$ She examines how to supplement open educational resources with lawful uses of copyrighted materials through existing licenses or limitations or exceptions in copyright law. She shows how South Africa's access to Generalized System of Preferences in the United States has been connected with reforms in South Africa's Copyright Amendment Bill as that Bill awaits Presidential assent. She makes a case for reviewing copyright laws to meet digital contexts of teaching as has been occasioned by COVID-19.

Rafia de Gama's essay zeroes in on reports that some Western scientists have problematically argued that vaccine trials in Africa have the benefit of testing in a place where, there are no masks, no medicines available to ease symptoms and no resuscitation. ${ }^{18}$ In addition to citing the World Health Organization's critique of this colonial mindset, she helpfully traces the international standards and treaties that govern the conduct of clinical trials that meet requirements such as informed consent. She argues that True informed consent would require an understanding of culture and language as well as take into account the actual and future needs that may impact informed consent. It is essential to keep at the forefront that informed consent is an ongoing process as the clinical trials.

Arunender Singhh's essay focuses on another BRICS country, India. ${ }^{19} \mathrm{He}$ argues that COVID-19 has opened up new challenges for the governments, especially, for populous countries like India to address issues such as fake news, data protection and privacy as well as child pornography. He argues that while rapid technological advances have provided governments with some ability to respond to the COVID-19 pandemic, it has become a double-edged sword. David Enrique Betancourt Cruz's essay focuses on the tension

\footnotetext{
${ }^{17}$ Caroline Ncube, "The Musings of a Copyright Scholar working in South Africa: is Copyright Law Supportive of Emergency Remote Teaching?" AfronomicsLaw (May 13, 2020).

${ }_{18}$ Rafia De Gama, "Clinical Trials and Its Regulations in Africa," AfronomicsLaw (May 14, 2020).

19 Arunender Singhh, "Protection of 'Digital Rights' Amid Fight Against COVID-19: The Missing

Responsibility of ICTs Platforms,” AfronomicsLaw (May 14, 2020).
} 
between intellectual property rights and access to medicines and treatments under patent. ${ }^{20}$ He brings a Latin American example to illustrate his argument. In so doing, he highlights the letter the President of Costa Rica sent to the World Health Organization Director requesting that access and use of intellectual property covering technologies that help detect, prevent, control and treat the COVID-19 be allowed. This "pool" of technologies, he notes, would include patents, copyrights, test data, research for diagnosis, treatment, medicines and vaccines, among others. He also addresses the utility of compulsory licenses and in doing so, revisiting many of the policy and legal debates that arose in the context of prior pandemics like HIV/AIDs. He argues the reform agenda of TRIPS Agreement that was incomplete from years past has become very pressing now.

Nciko Wa Nciko's essay focuses on how African countries have lost taxation rights over cross-border workers who have been evacuated from it but who are still deriving income from it through telework. ${ }^{21}$ After discussing the requirements of the UN and the OECD Model Tax Conventions for countries to have taxation rights over a cross-border worker, he argues that African countries should renegotiate the allocation of taxation rights over cross-border workers when teleworking is involved by using the UN Model.

While Nciko Wa Nciko focuses on innovations African countries should undertake, Jacquelene Wangui Mwangi uses actual examples of African innovations to deal with the COVID-19 pandemic as excellent examples of Africa's inventiveness that could be promoted by expanding the conceptualisation of intellectual property rights to include social innovation. ${ }^{22}$ Finally, Alex Kiragu and Patricia Ahawo Gwambo in their joint essay focus on the impact of the COVID-19 pandemic on Africa's agricultural markets as well as on food security. ${ }^{23}$ They propose solutions such as to protect those who innovate in the agricultural production space with intellectual property systems. Such systems, they argue should recognize the knowhow and practices of indigenous peoples to make sure that farmers get their rightful credit. In short, they argue that increasing support for farmers and agriculture in Africa is key to establishing the resilience necessary to feed Africa during a pandemic.

\section{WEEK THREE}

As noted above, in week 3, the Symposium will focus on the important issues the COVID19 pandemic raises relating to Sovereign Debt, Finance and Competition Law. Damola Adediji's contribution discusses the Nigerian Federal Consumer and Competition Authority's response to unreasonable and unfair pricing sparked by the COVID-19 pandemic and its relative silence on whether rules on horizontal coordination would

\footnotetext{
${ }^{20}$ David Enrique Betancourt Cruz, "An Exceptional International Intellectual Property Law Solution for COVID-19: Spurring Innovation to Facilitate Access to Affordable Medicines," AfronomicsLaw (May 15, 2020).

${ }^{21}$ Nciko Wa Nciko Arnold, "Who gets to Tax Global-North Citizens who have been Evacuated from Africa but who still derive Income from Africa through Telework?" AfronomicsLaw (May 15, 2020).

${ }^{22}$ Jacquelene Wangui Mwangi, "COVID-19 and the Unlocking of Innovation: Reflections on Law and Innovation in sub-Saharan Africa," AfronomicsLaw (May 16, 2020).

${ }^{23}$ Alex Kiragu \& Patricia Ahawo Gwambo, "Proposed Solutions for Sub-Saharan Africa for Food and Agriculture in the Context of COVID-19," AfronomicsLaw (May 16, 2020).
} 
continue to apply or whether there would be temporary exemptions to meet the exigencies of this pandemic period. ${ }^{24} \mathrm{He}$ compares its response to its counterparts in other jurisdictions.

Vellah Kigwiru Kedogo's essay extends these comparative institutional responses further, particularly in the context of trade restrictions that have been placed by countries to limit exports of essential supplies and medicines required to address the COVID-19 pandemic. $^{25}$ She favors responses by agencies that have promoted free trade and competition as a response to the COVID-19 pandemic, as opposed to those that have put restrictions in place. Some of the policy responses she discusses include permitting businesses to collaborate and coordinate as long as it is necessary to promote the public interest in response to the crisis. Her essay also discusses the challenges of African competition agencies remaining open through their online portals because of the lockdown.

Maria Adele Carrai's essay argues in favor of suspending or cancelling African sovereign debt because of the economic downturn of the COVID-19 pandemic and the fact that African countries were already experiencing massive financial gaps in funding before the pandemic. ${ }^{26}$ She echoes the recent editorial in the New York Times penned by Ethiopian Prime Minister Abiy Ahmed who argued failure to address Africa's debt problems may very well mean that the virus will 'bounce back to the rest of the world.' Carrai reminds us that the Economic and Monetary Community of Central Africa (CEMAC) suggested that member countries should collectively negotiate the cancellation of their external debts to give budgetary margins allowing them to deal with the pandemic and relaunch their economies. In the meantime, she notes that major creditors oppose debt forgiveness and that the World Bank while supporting a periodic suspension of debt repayment, has argued in favor of these countries undertaking 'structural reforms to help shorten the time to recovery and [to] create confidence that the recovery would be strong.'

Maria Elisa Vera Madrigal's innovative essay focuses on what she calls another silent epidemic that has accompanied COVID-19 pandemic funding, namely corruption. ${ }^{27}$ She centers her proposals on how this could be addressed in the Inter-American Convention Against Corruption as well as the Inter-American Human Rights Commission's resolution on Human Rights and Pandemics. She notes the importance of anti-corruption strategies targeted to the health care industry as well as the important role of transparency and monitoring that civil society groups can play.

Samuel Mwangi Muchori's contribution is on international financial institutions such as the African Development Bank's Environmental, Social, and Governance (ESG) Investing Framework, as well as its COVID-19 bond and the role they could play in addressing the

\footnotetext{
${ }^{24}$ Damola Adediji, "Coronavirus and Competition Law - A Commentary on the Nigerian Intervention, and Lessons from around the World," AfronomicsLaw (May 18, 2020).

${ }^{25}$ Vellah Kigwiru Kedogo, "COVID-19, Trade and Competition Law in Africa," AfronomicsLaw (forthcoming).

${ }^{26}$ Maria Adele Carrai, "African Sovereign Debt at a time of Pandemic: Legal Justifications for Suspension or Cancellation," AfronomicsLaw (forthcoming).

${ }^{27}$ Maria Elisa Vera Madrigal, "On Pandemics and Other Demons: Coronavirus-related Corruption and How to Prevent it," AfronomicsLaw (forthcoming).
} 
pandemic and financing African development. ${ }^{28}$ Rushmi Matete's essay emphasizes that in seeking discretionary financial support to address the COVID-19 pandemic, African countries should focus on fiscal programs targeting the most affected sectors and households so that they have money to spend on essential and basic needs. ${ }^{29}$ Like Maria Elisa Vera Madrigal, she emphasizes that there should also be transparency and accountability in managing the spending necessary to manage the impact of the COVID19 pandemic.

Danny Bradlow's essay proposes that the international community should create a Debts of Vulnerable Economies Fund (a "DOVE" fund) to help African countries deal with their private sector debt that currently totals over USD 130 Billion. ${ }^{30}$ The fund, he proposes could be created by the African Development Bank or the African Union. The fund, to be financed by governments, foundations, financial institutions, companies and individuals would have a primary goal of preventing vulture funds from speculating on a new crisis of African sovereign debt that is very likely to follow as a result of the COVID-19 pandemic. The DOVE fund would buy the debt of qualifying African states on financial markets at the market price (i.e. with the current steep discounts) and promise to implement a debt standstill on the debt it holds. Second, it would advocate that all other private sector creditors commit to a debt standstill as long as the crisis lasts and, on a case by case basis, to consider renegotiating the debt after the crisis ends. He ends by arguing that many of the financial institutions that hold African country debt have environmental, social and human rights policies that require them to comply with all applicable international standards, such as the Principles on Responsible Investing, the UN Guiding Principles on Business and Human Rights and the Equator Principles in their operations. Many also confirm that they respect all international human rights conventions. As such, the COVID 19 pandemic, Bradlow argues, is an opportunity for them to show that these public statements are not mere rhetoric but represent a meaningful change in their way of doing business.

After critically evaluating the social and economic impacts of the COVID-19 pandemic in Kenya, Jason Rosario Braganza's essay then discusses measures necessary to address the pandemic and to cushion the economy from the slowdown. ${ }^{31} \mathrm{He}$ emphasizes that it is particularly important for the government to shield the most vulnerable citizens, such as low-income earners and those in the informal economy, from the economic downturn through reliable safety nets and not merely through tax reductions that are likely to have little or no impact on them. Instead, he favors cutting VAT tax on essential goods. He does however praise the Kenyan government's allocation of about USD 93 million to the cash transfer programme as a good first step to address the economic consequences of the pandemic on the most vulnerable.

\footnotetext{
${ }^{28}$ Samuel Mwangi Muchori, “Global South International Financial Institutions and COVID-19 Response: Utilising Innovative Financing Solutions now and after the Pandemic," AfronomicsLaw (forthcoming). ${ }^{29}$ Rushmi Matete, "An African Perspective of Fiscal Policies and Debt management in the wake of the COVID-19 Pandemic," AfronomicsLaw (forthcoming).

${ }^{30}$ Danny Bradlow, "Doves, Vultures and African Debt in the Time of COVID-19," AfronomicsLaw (forthcoming).

${ }^{31}$ Jason Rosario Braganza, "PanDEBTmic - Potential Impact of the COVID-19 Pandemic in Kenya," AfronomicsLaw (forthcoming).
} 
Finally, on this theme, Tafadzwa H C Kwaramba's essay contextualizes the consequences the COVID-19 pandemic is likely to have on the indebtedness of commodity dependent economies. ${ }^{32}$ Thus, like Danny Bradlow, Kwaramba is interested in finding solutions to prevent the cyclical nature of sovereign debt.

\section{WEEK FOUR}

Finally, in Week 4, the Symposium will focus on Governance, Rights and Institutions. Gwinyai Regis Taruvinga's essay shows how the COVID-19 pandemic allowed Zimbabwean President Emmerson Mnangagwa's government to use the implementation of a violent lockdown to entrench itself in power further. ${ }^{33}$ Gwinyai argues that the Zimbabwean government has not only been ill prepared in responding to the pandemic but that it has excluded the opposition from participating in the decision-making. Gwinyai argues this non-inclusive response to the pandemic does not augur well for Zimbabwe since the opposition Movement for Democratic Change has forced a governance stalemate following claims of a stolen 2018 election. The response of the Zimbabwean government can, therefore, be said to have used the COVID-19 pandemic as a cover to justify its political crackdown on the opposition.

Kethi D. Kilonzo's contribution focuses on the difficulty of balancing the fundamental rights protected in the very liberal 2010 Constitution of Kenya, on the one hand, and the measures such as lockdowns and curfews that were imposed to address the COVID-19 pandemic, on the other. ${ }^{34}$ While she evaluates the responsiveness and adequacy of the Kenyan government's responses across a broad spectrum of issues, her essay squarely addresses the tensions between the fundamental rights to freedom of association, movement and access to justice, on the one hand, and lockdown imposed to limit the spread of the COVID-19 virus, on the other.

Tomasz Milej's essay helpfully discusses how to galvanize global solidarity to address the COVID-2019 pandemic. ${ }^{35}$ After examining various theories, he endorses George Scelle's notions of solidarity and a Kantian approach under which the government agents are committed not only to the interests of their respective nations but also to the interest of the international community as a whole. He notes these ideas correspond to the values underlying the African Charter of Human and Peoples' Rights. The role of the law at this moment of responding to the COVID-19 pandemic, Milej therefore argues, is pulling together for a common interest, for the public health to ensure a recovery, a healthy environment and a new international economic order in the aftermath.

Emmaqulate K. Morang's essay reflects on why the Kenyan Court of Appeal has eviscerated the protection and enforcement of social and economic rights and did not set

\footnotetext{
32 Tafadzwa H C Kwaramba, "Sovereign Debt and the COVID-19 Pandemic," AfronomicsLaw (forthcoming).

${ }^{33}$ Gwinyai Regis Taruvinga, "COVID-19 and Governance in Zimbabwe,” AfronomicsLaw (forthcoming).

${ }^{34}$ Kethi D. Kilonzo, "Playing tag with the Rule of Law: Balancing Fundamental Rights and Public Health in Kenya in the shadow of COVID-19," AfronomicsLaw (forthcoming).

35 Tomasz Milej, "Pandemic, Solidarity and the Foundations of International Law," AfronomicsLaw (forthcoming).
} 
Kenya up to prepare adequately to address the COVID-19 pandemic. ${ }^{36}$ She makes recommendations about how this could be changed. Dunia Prince Zongwe's graphic personal reflection argues the COVID-19 pandemic has reinforced inequalities among people and nations by forcing developing countries into the arms of richer nations in the West. ${ }^{37}$ Thus while he notes that, at least temporarily the pandemic has delinked Africa from the rest of the world as dependency theorists of the 1970s long argued in favor of, this temporary delinking is likely to exacerbate and accelerate Africa's dependency on the global capitalist system. He argues that policy makers, lawyers, and economists have not yet offered any alternatives to the neoliberal model of the current global capitalist system. Any alternative he argues would require massive resources and investments over a long period of time, and perhaps now is the least likely time for that.

Pedi Obani's essay focuses on the intersection of water, sanitation and hygiene, (WASH), services that are necessary to combat COVID-19, on the one hand, and international investment law, on the other. ${ }^{38}$ The essay also places its discussion in the context of the AfCFTA. Finally, the Symposium will close with Douglas de Castro and James Oliveira dos Santos essay, which reflects on how governments have securitized their national health responses to COVID-19. ${ }^{39}$ Using examples from Brazil and elsewhere, they show how the securitization of both the health sector and the economy have justified governments assuming more sweeping powers, including the suppression of constitutional rights and guarantees. They conclude that this securitization trends which pre-dates the COVID-19 pandemic should be checked to ensure that the measure governments take are consistent with human rights protections.

\section{Conclusion}

The excellent essays across the four themes, 'International Trade and International Investment Law and Policy' 'Intellectual Property, Technology and Agriculture' 'Sovereign Debt, Finance and Competition Law' and 'Governance, Rights and Institutions' raise salient issues and calls to action at the national, sub-regional, regional and international levels. The essays bring to the fore the important impacts of International Economic Law policy and practice in our current global order. While global solidarity is promoted to fight the pandemic, for example, the world leaders and experts open letter calling for a peoples vaccine against COVD-19, the case studies from around the world show that the varied approaches, measures and responses by national government have engendered different outcomes. Accordingly, the COVID-19 pandemic presents an unprecedented context and opportunity for Global South governments to critically reassesss and reimagine their International Economic Law policies and practices to ensure that domestic necessities and interests are priortised. We hope you enjoy these essays that our contributors so thoughtfully put together.

\footnotetext{
${ }^{36}$ Emmaqulate K. Morang'a, "COVID-19 and the State of Socio-economic Rights in Kenya: Why we must take these Rights Seriously," AfronomicsLaw (forthcoming).

${ }^{37}$ Dunia Prince Zongwe, “COVID-19 - The Great (Un)Equalizer,” AfronomicsLaw (forthcoming).

${ }^{38}$ Pedi Obani, "Human Rights Compatibility of Trade in WASH Services in the African Continental Free Trade Area," AfronomicsLaw (forthcoming).

${ }^{39}$ Douglas de Castro \& James Oliveira dos Santos, "Securitization of the Health and Economy in the COVID Times," AfronomicsLaw (forthcoming).
} 